\title{
KIM JAE-IK: HIS LIFE AND CONTRIBUTIONS
}

\author{
Kim Kihwan
}

Until his tragic death in Burma in 1983, Kim Jae-Ik was one of Korea's most gifted economists and a highly influential policymaker. Few were as dedicated to the cause of economic growth and development, and fewer still had as great an impact on Korea's economic policymaking. He played a key role in steering the Korean economy out of crisis in the early 1980s and was one of the chief architects of the liberal economic reforms launched in Korea.

The youngest of nine children, Kim Jae-Ik was born on November 26, 1938, into a family that owned substantial tracts of land in South Chungchong Province. He finished primary school in Seoul and went on to Kyonggi Middle School. During the Korean War his family's fortunes were reversed, and as a consequence the family suffered hardship and deprivation. Not only was his father killed, but three of his older brothers-one a young instructor at Seoul National University and the other two university students-disappeared during the war, presumably taken by North Korean troops. The destruction of his family relationship had a determining impact on his life. Responsible for his mother's welfare, Kim Jae-Ik took various part-time jobs to support his mother and put himself through school.

In spite of these hardships, he managed to do well academically. He passed a high school equivalency test in his junior year at Kyonggi High and went on to take the college entrance exam that earned him a place at Seoul National University, where he majored in international relations. Although it had only fifteen members, Seoul National's international relations class of 1960 boasted an extraordinary crop of students, including Suh Suk Joon, deputy prime minister and minister of 
economic planning, and Lee Kee Wook, vice minister of finance, both of whom were also killed in Rangoon. In addition to this network of friends, Kim Jae-Ik met another important person in his life at Seoul National University: the former Lee Soon Ja, a bright, energetic, and attractive French literature major, who later became his wife. They seemed a perfectly suited couple; he was reserved while she was outgoing. They were married in 1961.

Although Kim Jae-Ik wanted to pursue graduate studies after college, financial need forced him to take a job. After graduating from Seoul National in spring 1960, he joined the research department of the Bank of Korea, the nation's central bank. While holding a full-time job there, he continued his studies as a part-time graduate student at Seoul National University and received his master's degree in international relations in 1964. An opportunity to do graduate work on a fulltime basis came in 1966, when the East-West Center in Hawaii awarded him a scholarship in its master's program in economics. Two years later, with master's degree in hand, he enrolled at Stanford and earned his master's degree in statistics in 1972 and his Ph.D. in economics the following year.

While at Stanford, Kim Jae-Ik renewed his acquaintance with an individual who would have a major influence on his later career: Professor Nam Duck-Woo of Sogang University, who at the time was taking his sabbatical at Stanford. Nam had been among the first Koreans to receive a doctorate in economics in the United States, and he played a pioneering role in introducing modern economics into the university curriculum in Korea. Kim Jae-Ik had already met Nam in his Bank of Korea days, when he assisted him on a research project dealing with Korean monetary policy.

After finishing at Stanford, Kim Jae-Ik received several job offers from international organizations and universities in the United States, but decided to return to Korea in the early fall of 1973 and serve his country.

\section{KOREA'S ECONOMIC POLICY SHIFT IN THE 1970S}

In the early 1960s, when Kim Jae-Ik was beginning his career at the Bank of Korea, the Korean economy succeeded in its first economic take-off. This was in large part owing to the adoption of an outwardlooking development strategy that enabled the country to make good use of its comparative advantage in labor-intensive manufactured 
exports.' Thanks to this strategy, Korea's real GNP grew at an annual rate of 9 percent from 1962 to 1971 . Despite such remarkable success, the Korean government was making a policy shift toward import substitution in the early 1970 s. $^{2}$

Why such a shift occurred can best be understood in terms of the basic changes in the external and internal environment that Korea faced at that time. ${ }^{3}$ In 1971 the United States reduced its ground troop strength in Korea by a third. The Korean government saw this as the first step toward the eventual withdrawal of all U.S. troops from Korea. It was also around this time that Korea began to encounter growing protectionist barriers against its labor-intensive manufactured exports. What's more, the worldwide commodity boom of 1972-73 greatly inflated Korea's agricultural import prices, thereby putting great pressure on its balance of payments. In addition, the growing gap between rural and urban incomes, a consequence of rapid industrialization in the late 1960s, was becoming an important political and social problem.

In order to deal with these challenges, the government adopted a policy of accelerating the development of the heavy and chemical industries and achieving greater self-sufficiency in agricultural production. To accelerate the development of the so-called "strategic" industries, such as steel, shipbuilding, automobiles, machinery, and petrochemicals, the government extended low-interest loans and preferential tax treatment to these industries.

There is little question that these policy measures brought about an accelerated development of the heavy and chemical industries, but they did so at great cost to the country. The cheap credit and preferential tax treatment extended to strategic industries brought about inflation by stimulating growth in money supply. Furthermore, they gave rise to a serious structural imbalance in the economy. While the heavy and chemical industries suffered from excess capacity owing to overinvestment, the light industries suffered underinvestment because they were starved of funds. Because the light industries still accounted for the bulk of Korea's exports, this structural imbalance resulted in a decline in the

1. For a fuller description and analysis of the policy changes taken during this period, see Frank, Kim, and Westphal 1975, 197-200, and Hasan 1976, 54-78, 93-94. See also chap. 7 , sec. 3 .

2. The economic policies of this period were import-substitution policies in that domestic production replaced capital and intermediate goods that had previously been imported. For a description of these policies, see chap. 7, sec. 4 .

3. For a fuller analysis of the changes in Korea's external and internal environment, see Kim Kihwan 1985, 9-11. 
overall competitiveness of Korea's exports. With sluggish growth in exports came a slowing down of the nation's economic growth.

The policy of accelerating the development of the heavy and chemical industries also caused a setback in the remarkable gains in income distribution made in the 1960s. Investment in these capital-intensive industries failed to generate sufficient new employment opportunities. Furthermore, the rapid development of these industries increased the demand for skilled workers at the expense of unskilled workers, thereby driving a wedge between the wages of skilled and unskilled workers. In addition, the prices of ordinary consumer goods, on which lowerincome households spent a larger proportion of their income than upper-income households, rose much faster than the overall rate of inflation.

Government efforts to achieve self-sufficiency in agricultural products, particularly in staple grains, also created problems. To be sure, the price support programs adopted to achieve self-sufficiency brought about impressive gains in yield per acre as well as in farm incomes. But in operating the program, the government incurred large budget deficits, which added to inflationary pressures. By encouraging the production of grains at a time when demand was shifting to nongrain products, the program also contributed to a rise in overall food prices. ${ }^{4}$

\section{AT THE ECONOMIC PLANNING BOARD}

It was precisely in solving these problems of inflation, structural imbalance, loss of export competitiveness, slowdown in economic growth, and deterioration in income distribution that Kim Jae-Ik was to make his major contributions to Korea's economic policy later on. However, at the time he returned to Korea, he could not have foreseen these problems.

The first three years after his return to Korea were a period of reorientation for Kim Jae-Ik rather than of direct involvement in policymaking. Upon returning to the Bank of Korea, he was asked on a loan-basis to serve as an economic policy analyst in the Office of the President, commonly referred to as the Blue House. In 1974 Nam DuckWoo, with whom Kim Jae-Ik had spent so much time at Stanford, was appointed deputy prime minister and minister of economic planning. Upon assuming this position, Nam asked Kim Jae-Ik to join the Economic Planning Board (EPB).

4. See ibid., 11-15, for a fuller analysis of the effects of Korea's economic policies in the 1970s. 
Established in 1961, the EPB has the responsibility of formulating the nation's economic plans and the government budget. The head of the EPB also holds the title of deputy prime minister and serves as the nation's top economic policymaker. The EPB thus coordinates and controls conflicts among the economics ministries and generally has the last word on economic policy.

Because Korea's civil servants are normally selected on the basis of a formal examination, Nam arranged for Kim Jae-Ik to enter government service through special provisions, sparingly applied, that permit noncareerists of exceptional ability to enter government service in mid career. After a year as chief secretary to Deputy Prime Minister Nam, Kim Jae-Ik was appointed deputy director general of economic planning.

In $1976 \mathrm{Kim}$ Jae-Ik was promoted to the position of director general of economic planning. In this capacity, his job was basically overseeing the implementation of the policies designed to accelerate the development of the heavy and chemical industries. He soon became acutely aware of the many problems that have already been noted. Yet he was not in a position to do much about these problems, because during this period a great deal of the advice coming out of the EPB was being overruled by policymakers in the Blue House who were bent on accelerating the development of Korea's heavy and chemical industries, regardless of cost.

Nevertheless, Kim Jae-Ik managed to carry out two reforms of major significance during these years. In 1974 he made a study trip to Taiwan; where he found the electronic digital telephone switch system to be far more efficient than Korea's mechanical switching system. He felt that in the long run Korea would benefit greatly from an electronic switching system and strongly recommended its introduction. In doing so, he encountered serious opposition to a policy change for the first time in his government career. In opposing the shift to an electronic system, the local manufacturers of telecommunications equipment went so far as to question Kim Jae-Ik's personal integrity. Nevertheless, the change was made in 1980, which not only improved telephone service throughout the country but also provided Korea with an updated communications infrastructure and technology that has been vital in maintaining its competitiveness in the international markets.

The other major contribution was in public finance. In $1977 \mathrm{Kim}$ persuaded Deputy Prime Minister Nam to introduce a value-added tax (VAT) in Korea. The VAT proved to be a highly productive source of revenue compared to the eight special excise taxes it replaced, such as 
the business activity tax, petroleum products tax, and the textile products tax. By 1979 the VAT became the largest single source of government revenue, accounting for some 25 percent of the total. Being a universal and uniform tax, the VAT does not distort resource allocation. In spite of these merits, however, this new tax met with tremendous resistance from the general public, particularly from retail merchants, who prior to this change had tended to underreport earnings.

\section{THE 1980 ECONOMIC CRISIS}

Despite the many problems caused by the shift to an import-substitution strategy in the early 1970 s, fundamental changes in policy direction were not forthcoming until 1979. Toward the end of 1978, however, a cabinet reshuffle took place, providing an opportunity for Korea's policymakers to bring a new approach to tackling the nation's economic problems. In early 1979 the new deputy prime minister, Shin Hyon Hwak, asked Kim Jae-Ik and his bureau to formulate a comprehensive stabilization program that aimed at nothing less than restructuring the entire economy so as to enable the country to make full use of its potential for continued high growth. ${ }^{5}$

The stabilization program had four major components. To reduce excessive liquidity, the government set lower targets for growth in money supply and formulated reforms for the financial sector. To correct imbalances in the industrial sector, the government temporarily suspended all new projects in the heavy and chemical industries and made more credit available to the light manufacturing industries. The government also lifted price controls on many items in order to correct price distortions. Finally, the government took the first major steps toward liberalizing imports.

This stabilization program enjoyed some success. For example, the relaxation of price controls did lead to the normalization of prices by the end of 1979, and it put an end to artificial shortages of basic commodities caused by price controls and the practice of "dual pricing." On the whole, however, the effectiveness of the 1979 stabilization was limited by a number of external and domestic shocks. The second major oil shock

5. The best summaries in English of the objectives, rationale and contents of the policy measures taken in the stabilization program can be found in the speeches by Shin Hyon Hwack, then deputy prime minister and minister of economic planning, and by Kang Kyong Shik, then assistant minister of economic planning, both given to the Tenth Annual Meeting of the International Economic Consultative Group for Korea, June 20, 1979, Paris. 
came only three months after the program was launched, and Korea's oil import bill nearly doubled in the following twelve months. The resulting strain on the nation's balance of payments made it impossible for Korean policymakers to continue with their import liberalization program. Furthermore, the worldwide recession brought about by the oil shock considerably reduced the growth of Korea's exports.

On the domestic front the assassination of President Park Chung Hee in October 1979 threw the country into political confusion. By the spring of 1980 this confusion had turned into a full-blown crisis. Violent student demonstrations and strikes by the labor unions were the order of the day. Under these conditions employers gave in easily to demands for excessively large wage hikes, and they had little reason to invest, given the great political uncertainty of the nation. To make things worse, an unusually cold, damp summer led to a disastrous harvest that year, agricultural production dropping by no less than 22 percent. As a result of these unfavorable developments, the Korean economy suffered negative growth for the first time in two decades, contracting by 5.2 percent, while inflation soared to 29 percent in consumer prices and 39 percent in wholesale prices. Korea's current account deficit ballooned to over $\$ 5.3$ billion.

In May 1980, a new de facto government emerged in the form of the National Emergency Council headed by General Chun Doo Hwan. In order to meet the crisis head-on, the council brought in Kim Jae-Ik and a number of his like-minded colleagues, who were eager not only to propose measures to pull the economy out of crisis, but also suggest wideranging reforms to restore to the economy its rich growth potential. In July $1980 \mathrm{Kim}$ Jae-Ik was appointed chairman of the Committee on Economic and Scientific Affairs of the National Emergency Council. In this capacity Kim Jae-Ik's responsibilities were twofold: to deal with urgent day-to-day economic management problems and to prepare an agenda for reform. He and his staff worked feverishly throughout the summer. Upon the inauguration of the new government of President Chun Doo Hwan in September 1980, Kim Jae-Ik was appointed senior secretary to the president for economic affairs. He served in this post until he died in Rangoon on October 9, 1983.

It was as the president's senior economic advisor that Kim Jae-Ik had the greatest influence on the nation's economic policy direction. The senior secretary to the president for economic affairs wields much more power and influence than the title may imply, because he is in constant contact with the president. Owing to this proximity to the president, the 
senior secretary can and often does speak in the president's name and has considerable influence on appointments to high-level economic positions. Furthermore, although the deputy prime minister is Korea's highest economic policymaker, differences of views on economic policy occasionally arise at the cabinet level that even he cannot resolve. In such cases, the senior secretary often steps in to help resolve the conf licts.

\section{ACHIEVING PRICE STABILITY}

Soon after it was established, the new government launched wideranging economic policy reforms based on the agenda prepared by Kim Jae-Ik and his colleagues. The agenda highlighted three main objectives: achieving price stability, restoring growth, and improving the distribution of income. ${ }^{6}$

The policies for achieving price stability that Kim Jae-Ik and his colleagues formulated had in turn three major thrusts. The most important was to reduce the government deficit. In the Korean context, as long as the government had a deficit, the nation's central bank had no option but to finance it through money creation. For this reason, Kim Jae-Ik worked very hard to achieve a balanced budget for the entire government sector. The essential part of this effort was reducing the subsidies to public enterprises, as well as to a number of special accounts, such as the Grain Management Fund and the National Investment Fund. The most drastic step taken by the government to achieve a balanced budget was the 1983 decision to freeze total expenditure for the following year. As a result of these efforts, the total government deficit as a percentage of GNP fell from 4.7 percent in 1981 to 1.4 percent in 1984.

The second major thrust lay in tightening monetary policy. Not only was the targeted growth in money supply reduced, but the nominal interest rate on bank deposits was raised so as to make the real interest rate positive. As a result the annual growth in money supply, broadly defined, which stood at 26.9 percent in 1980 , was brought down to 15.2 percent in 1983 and 7.7 percent in 1984.

The third major thrust was to restrain the growth in wages. The government first announced a small increase in wages for the public sector and then used this announcement to limit wage increases in the private

6. See Kim Jae-Ik 1983 for his views on price stability, continued economic growth, and improved distribution of income. 
sector. The banks reinforced this policy by urging private firms to reduce their debt/equity ratios if they wanted to grant wage increases higher than the rise in productivity. In this way, the annual increase in money wages was reduced sharply from over 30 percent in the late 1970 s to 11 percent by 1983 and to less than 9 percent in 1984 .

A discussion of Kim Jae-Ik's efforts to bring inflation under control would not be complete without mention of the land registration system. A problem that continued to plague Korean policymakers in their fight against inflation was the rampant speculation in real estate, which not only fanned inflationary psychology but diverted savings to socially unproductive investment. What made curbing such speculation difficult was the lack of a timely record of who was buying and selling property; without such a record, individuals were free to speculate in as many property deals as they could afford. The opportunity to move decisively to curb this speculation came in the summer of 1983 on the heels of a scandal in which the Myung Sung business group was found to have illegally channeled bank funds into large-scale speculation in real estate. Riding on the public outcry that ensued, Kim Jae-Ik initiated work to establish a computerized system of land registration that would promptly record all real estate transactions.

\section{PROMOTING GROWTH THROUGH STRUCTURAL REFORMS}

Kim Jae-Ik and his colleagues in government felt very strongly that the best way for Korea to maintain its growth momentum would be by achieving greater efficiency in the allocation of resources through the market. To this end, they went about liberalizing external economic policies and promoting competition in every sector of the economy internally. The heart of the liberalization of the nation's external economic policies was a preannounced schedule whereby market-opening measures would be published well in advance in order to alert businesses to prepare for market opening and make necessary adjustments. In accordance with this approach, adopted in 1981, the Korean government steadily liberalized its import regime. As late as 1979 , only 68 percent of all products were allowed to enter Korea without prior import licensing. Since that time, the import-liberalization ratio has continued to rise: the ratio, which stood at 76.6 percent in 1982 , rose to 84.8 percent by 1984 and 91.5 percent by 1986 , and by 1988 almost all industrial products entered Korea subject only to tariffs. ${ }^{7}$ In addition to removing nontariff

7. For a discussion of the practical significance of these figures, see chap. 7 , sec. 5 . 
barriers in this manner, the policy reformers sought not only to reduce the average tariff rate but also to narrow tariff differentials among different items.

In the months following the assassination of President Park, Kim Jae-Ik and his colleagues were very concerned about the possibility that foreign investors in Korea might pull out of the country owing to political uncertainty and the deteriorating investment climate. They were determined to take bold steps to liberalize policy on foreign investment in order to forestall this possibility. To this end, in September 1980 the government allowed foreign investors up to a 100 percent equity share in many industries, while for the time being maintaining existing tax incentives and other benefits for foreign investors.

Kim Jae-Ik was convinced that Korea could not become an industrially advanced nation unless it undertook fundamental reforms in the financial sector. Furthermore, he had the view that Korea should someday become a new financial center of Asia, in the manner of Singapore and Hong Kong. In 1980, with these objectives in mind, he played a key role in establishing two new commercial banks in joint ventures with foreign entities.

Kim Jae-Ik knew, of course, that the first essential step to liberalize the banking sector would be to denationalize Korea's major commercial banks. He had long been waiting for an opportunity to implement reform. The opportunity finally came in the summer of 1982, when the so-called curb market scandal rocked the very foundations of the nation's financial system. ${ }^{8}$ Capitalizing on this crisis, he succeeded in persuading the top policymakers in government to relinquish government holdings in the country's major commercial banks during the following year.

A major step that Kim Jae-Ik and his colleagues took to promote competition throughout the economy was to enact a law prohibiting monopolistic practices and collusion among firms. Thanks in large measure to their efforts, such legislation was passed in 1981, and soon there-

8. The curb market scandal of 1982 basically involved huge loans extended by an individual named Chang Young-ja to a large number of Korean companies that were caught in a liquidity crisis. What made Chang's operation highly unusual was that she received from her borrowers as collateral a large quantity of short-term "accommodation" bills far in excess of the value of the loans. She used these bills to obtain additional funds by discounting them heavily in the short-term financial market. When the bills so transacted in the market were presented for payment, it was beyond the capacity of the original issuers and the banks that had endorsed them to make good, and thus the financial crisis ensued. 
after the Fair Trade Commission was established within the Economic Planning Board to enforce it.

One of Kim Jae-Ik's priorities in achieving greater efficiency in investment allocation was to phase out the practice of extending preferential access to credit and favorable taxation policy to "strategic industries." This preferential treatment was gradually replaced by equal incentives for investment, technology development, and manpower training in all industries, thereby allowing all firms and industries to compete on their own merits.

Kim Jae-Ik also attempted major reforms in the area of taxation. In 1983 he and his colleagues in government proposed significantly to reduce the highest marginal rate on both corporate and personal income taxes. They did not succeed, however, in obtaining the reductions they had hoped for. The national legislature, overly concerned about the possible shortfall in revenue, made only a small downward adjustment: the highest marginal tax rate on corporate income was reduced from 38 to 30 percent and that on personal income from 65 to 55 percent.

Kim Jae-Ik placed great importance on the promotion of science and technology as the basis on which to sustain Korea's long-term economic growth and development. His efforts to promote science and technology included lobbying for greater budgetary allocations for research and development, expanding industrial extension services by organizations such as the Small-Medium Industry Advancement Corporation, and encouraging venture capital in Korea. In addition, he played a key role in launching the Science and Technology Promotion Council, a powerful body consisting of high-level government officials and business and academic leaders, which meets quarterly to review the nation's progress in the field of science and technology under the chairmanship of the nation's president.

\section{IMPROVING INCOME DISTRIBUTION: MACRO-MICRO APPROACH}

Kim Jae-Ik believed that any governmental efforts to improve income distribution should center around the expansion of employment opportunities through continued high growth with price stability. He reasoned that in a competitive economy, the expansion of employment opportunities with a low level of inflation is bound to bring about a steady increase in the real wages of workers and income.

Critical as these macroeconomic policy efforts were, Kim Jae-Ik believed that they should be supplemented with a number of micro- 
economic programs. In his thinking, the most crucial element in this approach was increasing access to education for all groups in society. $\mathrm{He}$ often cited the experience of many industrialized countries showing that enlarging educational opportunities is the surest way of guaranteeing equitable income distribution in the long run, while increasing the supply of skilled and technical manpower in the short run.

Because of this belief in the value of education, in $1978 \mathrm{Kim} \mathrm{Jae}-\mathrm{Ik}$ spearheaded efforts to raise the ceiling on the number of students entering university each year. Thanks to this effort, university enrollment rose from some 330,000 in 1979 to 870,000 in 1984. In addition, he exerted all his influence to increase government expenditure on education and vocational training. In part owing to his efforts, public expenditure on education as a percentage of the total government budget rose from 17 percent in 1980 to 19 percent in 1984 .

Another important element in the microeconomic approach to improving income distribution favored by Kim Jae-Ik was increasing the supply of housing units within the reach of low-income families. To this end, he succeeded in persuading the Seoul city government to develop a large tract of land where small, cheap housing units could be built. Kim Jae-Ik also believed that expanding public services and facilities would go a long way toward improving the welfare of low-income groups. For this reason, he was a strong advocate of expanding Seoul's subway system as well as of building more parks and recreational facilities in Seoul and other urban areas.

The approach to improving income distribution espoused by Kim Jae-Ik and his like-minded colleagues has apparently worked well. From 1980 to 1984 the percentage of national income held by the lower 40 percent of Korean households rose from 16.1 to 18.9 percent, while that accounted for by the upper 20 percent declined from 45.4 to 42.3 percent, ${ }^{9}$ leading many foreign scholars and international organizations, including the World Bank, to point out that Korea's record with regard to income distribution is second only to that of Taiwan.

\section{KIM JAE-IK THE POLICYMAKER}

How was Kim Jae-Ik able to bring about so many economic policy reforms despite his relatively short career in government? The answer lies in his deep understanding of how government works and his outstanding personal qualities. The greatest obstacle to policy changes in any

9. See Suh 1985, 22. 
country is the resistance change itself always encounters. The status quo has its defenders, especially among those who administer or benefit from existing regulations. Thus when an external event occurs that demands a policy response-a crisis of some sort-an opportunity is created to improve policy. Kim Jae-Ik understood this very well and capitalized upon such moments to promote policy changes that he had previously determined to be desirable. He also recognized that the public had to be willing to accept policy change. In order to increase public understanding of the merits of market-oriented solutions to economic and social problems, he organized many educational efforts in the form of public seminars, workshops, and television programs.

Kim Jae-Ik also had a remarkable combination of personal characteristics that made him effective in a governmental setting; he was an easy person to agree with. He was genuinely modest and soft-spoken, but that did not keep others from recognizing that he had a brilliant mind. He could persuasively and persistently argue for his positions. He knew how to marshal facts, figures, and logic for his case for the purpose of convincing others rather than overwhelming them.

Kim Jae-Ik was appreciated and trusted by his superiors and subordinates alike. He rarely claimed credit for his policy innovations. He enjoyed the full confidence and trust of even the highest public officials. He had a considerable case of workaholism, and he expected that of his staff; yet his enthusiasm for work was so infectious that subordinates became extremely loyal to him. He responded in kind by furthering their careers and promoting their welfare.

Finally, Kim Jae-Ik had deep philosophical convictions and a vision of the future of his country. He never doubted the superiority of the market over government fiat. To him, the market was not only more efficient in resource allocation but in the long run most conducive to the advancement of democracy. Furthermore, he believed that with liberal economic reforms and efficient management, Korea could one day emerge as a world-class industrial power. These beliefs and visions gave him tremendous strength and confidence. At all times he was serene, and to the end he was an optimist.

\section{REFERENCES}

Frank, Charles R., Jr., Kim Kwang-Suk, and Larry E. Westphal. 1975. South Korea. Vol. 7 of Foreign Trade Regimes and Economic Development. New York: National Bureau of Economic Research. 
Hasan, Parvez. 1976. Korea: Problems and Issues in a Rapidly Growing Economy. Baltimore: Johns Hopkins University for the World Bank.

Kang Kyong Shik. 1979. "Korea's Recent Economic Policy Adjustments and Requirement for Foreign Capital." In Report on the Tenth Annual Meeting of the International Economic Consultative Group for Korea. In Korean. Seoul: Economic Planning Board.

Kim Jae-Ik. 1983. "The Korean Economy: Current Reforms and Future Prospects." Speech to the Annual Conference of the Hong Kong Management Association. Hong Kong, October 3.

Kim Kihwan. 1985. The Korean Economy: Past Performance, Current Reforms, and Future Prospects. Seoul: Korea Development Institute.

Korea, Republic of. Economic Planning Board. 1986. The Sixth Five-Year Economic and Social Development Plan. In Korean. Seoul: Economic Planning Board.

Shin Hyon Hwack. 1979. "New Challenges and Opportunities for the Korean Economy." In Report on the Tenth Annual Meeting of the International Economic Consultative Group for Korea. In Korean. Seoul: Economic Planning Board.

Suh Song-Mok. 1985. "Economic Growth and Change in Income Distribution: The Korean Case." Working Paper no. 8508. Seoul: Korean Development Institute. 